\title{
First records of Fistularia petimba and Diodon eydouxii for the Azores, with notes on the occurrence of three additional species
}

\author{
J. M. N. Azevedo*†, P. M. Raposeiro* And L. Rodrigues \\ *Universidade dos Açores, Departamento de Biologia, Apartado 1422, 9501-801 \\ Ponta Delgada, Portugal and \$Associação Maritima Açoreana, Rua do \\ Pires, 71 Rabo de Peixe, 9600 Ribeira Grande, Portugal \\ (Received 14 July 2003, Accepted 9 July 2004)
}

\begin{abstract}
Two new records of fishes from the Azores are reported: Fistularia petimba and Diodon eydouxii. The occurrence of Centracanthus cirrus, Decapterus macarellus and Priacanthus arenatus in Azorean waters is confirmed.

(C) 2004 The Fisheries Society of the British Isles
\end{abstract}

Key words: Carangidae; Centracanthidae; Diodontidae; Fistularidae; Priacanthidae.

The number of marine fish species recorded in the Azores has risen sharply throughout the 20th century, from $<150$ to the current number of 460 (Santos et al., 1997). This increase reflects, on one hand, the sustained effort of collecting and identifying by several generations of local and foreign researchers. On the other hand, records of warm water species outside their normal range are common. In the last 20 years, 34 non deep-water species have been recorded. Over $70 \%$ of these are tropical or sub-tropical (Santos et al., 1997; Froese \& Pauly, 2003) and many are pelagic and cosmopolitan. Given the isolated position of the Azores (Fig. 1), records of unusual components of the marine fauna are relevant in the present discussion of climate change.

Methods of taking counts and measurements follow Hubbs \& Lagler (1964), except for Diodon eydouxii Brisout de Barneville where Leis (1978) was followed. Abbreviations used: DOP, Departamento de Oceanografia e Pescas, Universidade dos Açores; NMNH, National Museum of Natural History, Smithsonian Institution; MCM, Museu Carlos Machado, Ponta Delgada.

Family Fistulariidae

Fistularia petimba Lacepède, 1803. Fig. 2(a).

Material: MCM 956, 21.X.2000, $1007 \mathrm{~mm}$ standard length $\left(L_{\mathrm{S}}\right)$, São Miguel, outside Porto da Lagoa $\left(37^{\circ} 44^{\prime} 24^{\prime \prime} \mathrm{N} ; 31^{\circ} 35^{\prime} 08^{\prime \prime} \mathrm{W}\right)$. Line fishing, $10 \mathrm{~m}$ depth.

$\dagger$ Author to whom correspondence should be addressed. Tel.: +351 296650 113; fax: +351296650 100; email: azevedo@notes.uac.pt 


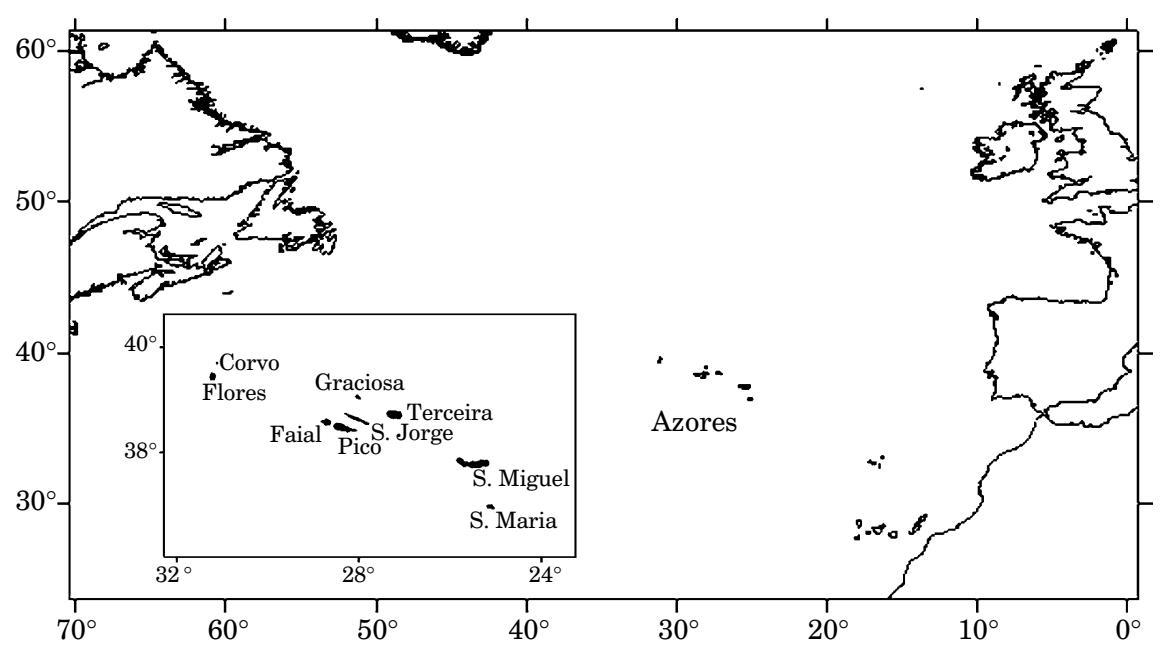

FIG. 1. Position of the Azores in the North Atlantic.
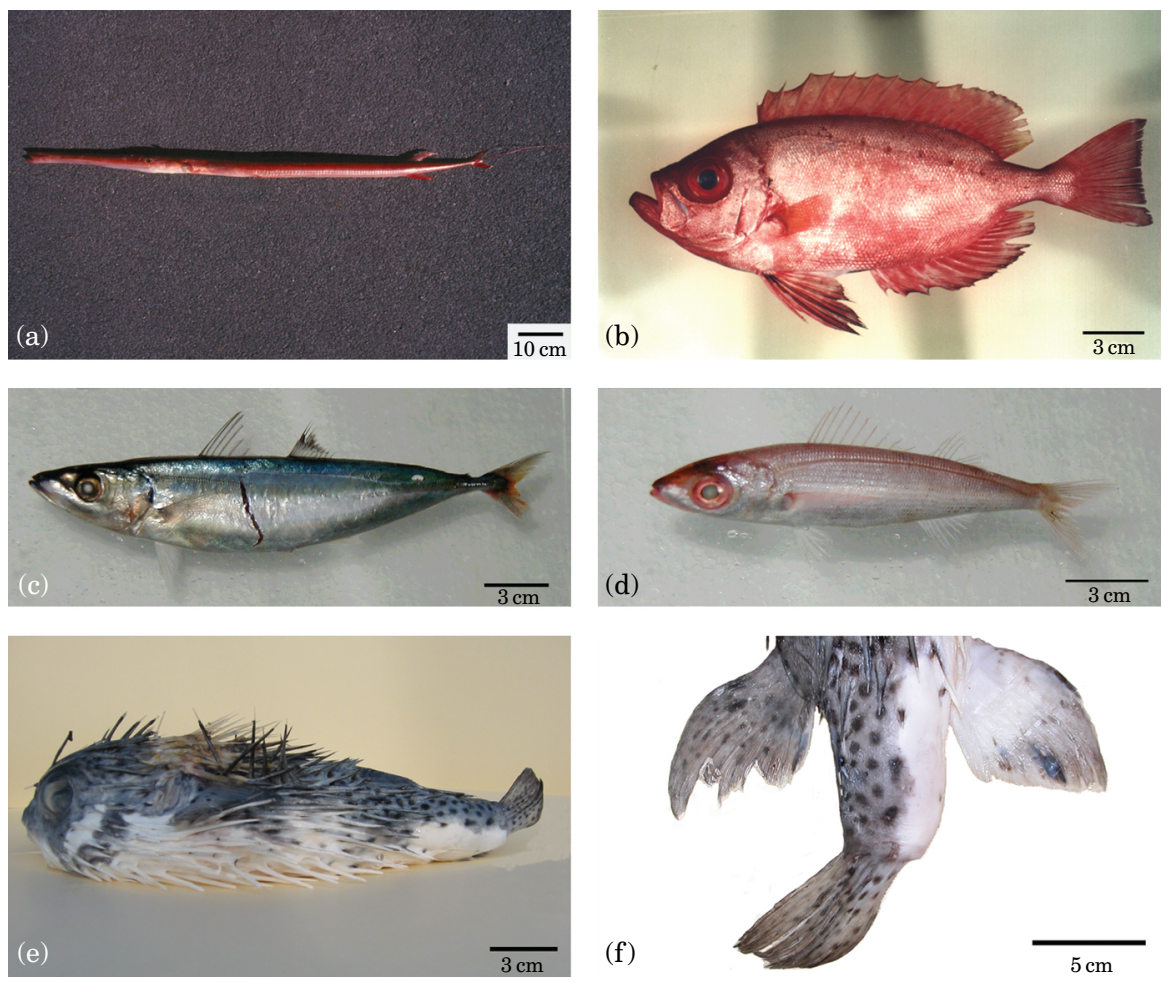

Fig. 2. (a) Fistularia petimba, $1007 \mathrm{~mm} L_{\mathrm{S}}$, MCM 956, (b) Priacanthus arenatus, $215 \mathrm{~mm} L_{\mathrm{S}}$, MCM 960 , (c) Centracanthus cirrus, $140 \mathrm{~mm} L_{\mathrm{S}}$, MCM 957, (d) Decapterus macarellus, $219 \mathrm{~mm} L_{\mathrm{S}}$, MCM 958 and (e) Diodon eydouxii, $270 \mathrm{~mm} L_{\mathrm{S}}$, MCM 959, with (f) detail of dorsal, anal and caudal fins. 
Characteristics: reddish; D 15; A 14; pelvic fin rays 6; pectoral fin rays 15; no gill rakers; row of bony plates along the midline.

Measurements (in $\mathrm{mm}$ ): predorsal length 830, head length 373, length of dorsal fin base 34, snout length 284, eye length 23, post-orbital head length 65 , length of the upper jaw 29 , height of pelvic fin 28 , length of the base of the anal fin 32 , least depth of the caudal peduncle 10 .

Distribution: tropical in the Atlantic and Indo-Pacific. The north-eastern limit of distribution in the Atlantic is Cape Blanc and Cape Verde (Fritzsche, 1990). One record from Cadiz, on the Mediterranean (Cárdenas et al., 1997).

Remarks: on two separate occasions during the summer of 2000 a similar fish was observed by scuba divers (C. Rodrigues at Caloura and J. Brum at Ponta Delgada harbour, pers. comm.). From their descriptions of longitudinal stripes and of spots near the tail, however, it is more likely to have been Aulostomus strigosus Wheeler, 1955. An undetermined species of Fistularia, from a single specimen captured off Faial Island in 1955, is mentioned in correspondence between B. Collins and G. Maul, but the specimen was subsequently lost (Santos et al., 1997).

Family Priacanthidae

Priacanthus arenatus Cuvier in Cuvier \& Valenciennes, 1829. Fig. 2(b).

Material: MCM, 960, 7.X.2002, $215 \mathrm{~mm} L_{\mathrm{S}}$, São Miguel, outside Ponta Delgada Harbour. Gillnet, shallow water, coll. Emídio de Sousa, Santo António. Characteristics: eyes large, body compressed, colour reddish, mouth oblique; D X, 14; A III, 15; lateral line scales 69. Pectoral fin rays 18; gill rakers $4+25$.

Measurements (in mm): total length $\left(L_{\mathrm{T}}\right) 255$; fork length $\left(L_{\mathrm{F}}\right) 215$; predorsal length 70; head length 68; length of dorsal fin base, spinous portion 73, softrayed portion 50; snout length 11; eye length 22, post-orbital head length 20 , length of the upper jaw 30, height of pelvic fin 64, length of the base of the anal fin 64, least depth of the caudal peduncle 17.

Distribution: tropical areas of the Atlantic, know northward to Madeira on the eastern Atlantic (Starnes, 1988).

Remarks: according to Santos et al. (1997), many specimens are deposited at DOP, the first one having been caught in 1987.

Family Carangidae

Decapterus macarellus (Cuvier, 1833). Fig. 2(d).

Material: MCM 958, 10.XII.2001, one specimen, Ponta Delgada fish market, São Miguel.

Characteristics: bluish above, silver below; caudal fin reddish. D VIII + I, 33; A damaged; pelvic fins I +4 ; curved lateral-line scales 106; straight lateral-line scales 25; gill rakers $12+37$.

Measurements (in mm): $L_{\mathrm{T}} 252 ; L_{\mathrm{F}} 230$; predorsal length 77; head length 57; length of dorsal fin base, spinous portion 28, soft-rayed portion 21; snout length 19; eye length 13 , post-orbital head length 22 , length of the upper jaw 17 , height of pelvic fin 22 , length of the base of the anal fin 25 , least depth of the caudal peduncle 6 .

Remarks: this species was previously reported for the Azores by Santos et al. (1997), but no specimens are mentioned. According to the reports of fishermen, 
this species was unknown in the fish market of Ponta Delgada until the winter of 2002, when large numbers were caught. It was captured either alone or in mixed schools with Trachurus sp. Reliable statistics are not available because the species is not separated from Trachurus sp. in the market records.

\section{Family Centracanthidae}

Centracanthus cirrus Rafinesque, 1810. Fig. 2(c).

Material: MCM 240, no date, two specimens, São Miguel; MCM 957, 10.XII.2001, 11 specimens, São Miguel, fish market, Ponta Delgada.

Characteristics: reddish above, silvery below, caudal fin yellow reddish, pelvic fin reddish; D XIII, 10; A III, 9; pelvic fins I, 4; lateral line 90.

Measurements (in mm): $L_{\mathrm{T}} 171, L_{\mathrm{F}} 157$, predorsal length 54 , head length 40 , length of dorsal fin base, spinous portion 42, soft-rayed portion 17, snout length 13, eye length 12 , post-orbital head length 16 , length of the upper jaw 13 , height of pelvic fin 20, length of the base of the anal fin 18, least depth of the caudal peduncle 9.

Distribution: Mediterranean. eastern Atlantic, from Portugal to Morocco westward to Azores, Madeira and the Canary Islands (Heemstra, 1990).

Remarks: this species was previously reported for the Azores over a century ago (Regan, 1903), based on two specimens today at the MCM. Three additional specimens, collected in 1894, are deposited in the NMNH (USNM 94455). According to fishermen, however, this species is common in the catches around the island of São Miguel, although with variations between years. It is variously know under the common Portuguese names of 'biqueirão' or 'piriti'. It is specially common around Nordeste, where it is mainly fished by boats from Ribeira Quente. It is normally captured in association with Boops boops (L.), with which it is grouped in fish market records.

\section{Family Diodontidae}

Diodon eydouxii Brisout de Barneville, 1846. Fig. 2(e), (f).

Material: MCM 959, 24.VII.2002, $270 \mathrm{~mm} L_{\mathrm{S}}, 37^{\circ} 23^{\prime} \mathrm{N} ; 33^{\circ} 01^{\prime} \mathrm{W}$, caught floating at the surface, recently dead, coll. IRIS DO MAR.

Characteristics: back and sides blue, with small elongate black spots; dark gular band, belly silvery white; dorsal and caudal fins with dark spots, a few dark spots also on the anal fin [Fig. 2(f)]; anal and dorsal fins pointed [Fig. 2(f)]; D 16, A 17, pectoral fins 21; 11 spines from lower jaw to anus; head width $3 \cdot 3$ in SL.

Measurements (in $\mathrm{mm}$ ): $L_{\mathrm{T}} 346, L_{\mathrm{S}} 270$, head length 97 , length of dorsal fin base soft-rayed portion 32, snout length 28 , eye length 19 , post-orbital head length 154, length of the upper jaw 4, length of the base of the anal fin 31 , least depth of the caudal peduncle 28.

Remarks: this species has been confused with Diodon hystrix L. (Brito et al., 2002). This latter species is littoral, with a generally brown colouration and rounded anal and dorsal fins; D. eydouxii is, in contrast, a pelagic species, with back and sides blue and belly white, and pointed anal and dorsal fins (Leis, 1978). It is possible that some of the records of D. hystrix for the Azores are in fact misidentified D. eydouxii.

All of these species have tropical or sub-tropical affinities. The present results, therefore, are additional evidence of new tropical fish records in the warm 
temperate habitat of the Azores. To link this trend with a persistent faunal change associated with global warming, however, mere faunal records are not enough. Dedicated, long-term studies of the relative abundance of the littoral fish fauna need to be analysed in the light of the biogeographic affinities and ecological requirements (tropical, sub-tropical and warm temperate) of each species. Nevertheless, these records are scientifically noteworthy and may assist more detailed studies in the future.

\section{References}

Brito, A., Pascual, P. J., Falcón, J. M., Sancho, A. \& González, G. (2002). Peces de las islas Canarias. Tenerife: Francisco Lemus.

Cárdenas, S., Berastegui, D. A. \& Ortiz, J. M. (1997). First record of Fistularia petimba Lacepéde, 1803 (Pisces, Fistulariidae) off the coast of Cadiz (southern Iberian Peninsula). Boletin del Instituto Español de Oceanografia 13, 83-86.

Fritzsche, R. A. (1990). Fistulariidae. In Check-list of the Fishes of the Eastern Tropical Atlantic (CLOFETA) (Quero, J. C., Hureau, J. C., Karrer, C., Post, A. \& Saldanha, L., eds), pp. 654-655. Lisbon: JNICT, and Paris: SEI and UNESCO.

Heemstra, P. C. (1990). Centracanthidae. In Check-list of the Fishes of the Eastern Tropical Atlantic (CLOFETA) (Quero, J. C., Hureau, J. C., Karrer, C., Post, A. \& Saldanha, L., eds), pp. 768-772. Lisbon: JNICT, and Paris: SEI and UNESCO.

Hubbs, C. L. \& Lagler, K. (1964). Fishes of the Great Lakes Region. Ann Arbor, MI: University of Michigan Press.

Leis, J. M. (1978). Systematics and zoogeography of the porcupine-fishes (Diodon, Diodontidae, Tetraodontiformes) with comments on egg and larval development. U.S. Fishery Bulletin 76, 535-567.

Regan, C. T. (1903). On a collection of fishes from the Azores. Annals and Magazine of Natural History 7, 344-348.

Santos, R. S., Porteiro, F. M. \& Barreiros, J. P. (1997). Marine fishes of the Azores: Annotated checklist and bibliography. Arquipélago-Life and Marine Sciences, Supplement 1 .

Starnes, W. C. (1988). Revision, phylogeny and biogeographic comments on the circumtropical marine percoid fish family Priacanthidae. Bulletin of Marine Science 43, 117-203.

\section{Electronic Reference}

Froese, R. \& Pauly, D. (Eds) (2003). FishBase. World Wide Web Electronic Publication (version 16 June 2003). Available at http://www.fishbase.org 